\title{
Why do Young People Give up Their Job Search?'
}

\section{Sami Ylistö ${ }^{2}$}

Project researcher, University of Jyväskylä, Department of Social Sciences and Philosophy, Finland

\begin{abstract}
The decision to search or not to search for work is usually considered a purely individual choice. However, this is a simplistic view, which ignores important structural and situational aspects of job search behaviour. This article discusses the reasons why long-term unemployed youth in Finland give up their search for work or a student place. The data comprise 28 life course interviews that were analysed by means of content analysis. The data show that young people's job seeking behaviour is greatly influenced by how they view their labour market position and prospects. Job search abandonment is often temporary and young people soon resume their search because of the expectations of the society around them and their willingness to find work. The young people interviewed provided rational, emotional and life value reasons for their decision to suspend their job search. The article offers a deeper understanding of youths' job search behaviour.
\end{abstract}

\section{KEYWORDS}

Youth unemployment / long-term unemployment / job search obstacles

\section{Introduction}

ost European countries have seen a sharp rise in youth unemployment following the economic crises of the 1990s (Thompson 2013, p. 11) and 2000s (Dietrich 2012 , p. 4). Youth unemployment rates are more than twice as high as figures for adults, but there is a significant variation between European countries (Dietrich 2012, p. 13) because of differences in vocational and educational systems (Breen 2005). In Finland, the 1990s economic crisis pushed up the youth unemployment rate very sharply (Myrskylä 2010, p. 18). Figures then fell back somewhat, only to rise again in the wake of the 2007 economic downturn (Dietrich 2012, p. 4). Today, the Finnish youth unemployment rate is still higher than in EU28 countries (Eurostat 2017) on average. ${ }^{1}$ Compared with the other Nordic countries, Finland's youth unemployment rate is quite close to Sweden's, while Denmark, Iceland and Norway have significantly lower levels of youth unemployment. In Finland and the other Nordic countries, youth long-term unemployment is considerably lower than in the other European countries (Dietrich 2012, p. 18).

There have also been marked changes in European labour force policies over the past three decades. Most significantly, there has been a growing shift towards activating the unemployed, instead of pursuing full employment through direct job creation

\footnotetext{
${ }^{1}$ You can find this text and its DOI at https://tidsskrift.dk/njwls/index.

${ }^{2}$ Corresponding author: Sami Ylistö, Department of Social Sciences and Philosophy, PO Box 35, University of Jyväskylä, Jyväskylä 40014, Finland. E-mail: sami.ylisto@jyu.fi.
} 
or Keynesian demand management (Keskitalo 2008, p. 103). The policy of activation has also tightened the conditions for benefit receipt, making eligibility increasingly dependent on labour market participation (Keskitalo \& Karjalainen 2013, p. 8). Active labour market policies have been viewed as ways of mobilizing available labour resources and improving overall labour productivity, reducing unemployment, and fostering incentives to work (see Johansson \& Hviden 2007, p. 336, 339). Young people have been an important target for these active labour market measures, and will remain so in the future. Various labour market schemes have been put in place across EU countries to facilitate the entry of young people into the labour market (Dietrich 2012, p. 9; Karjalainen 2013, p. 217).

Although the Nordic countries by no means take the exact same approach to activation, their policies do share certain features in common. Broadly speaking, all citizens of working age in the Nordic countries are now facing the same employment requirements (Johansson \& Hviden 2007, p. 344). Activation policies require that the unemployed must actively search for work and accept job or training offers (Hobbins 2016, p. 43; Johansson \& Hviden 2007, p. 337; Keskitalo 2008, p. 135). Job seeking thus lies at the core of all activation efforts. The thinking is that unemployment at a young age is particularly liable to lead to passivity and to detract from the motivation to find work (Hobbins 2016, p. 45). In this framework, a low level of job search intensity is usually interpreted as a sign of laziness or lack of motivation: these people tend to be considered workshy. This explanation is far from satisfactory, however, as it focuses exclusively on the individual and ignores the structural or situational factors that underlie job-seeking behaviours. This is why more in-depth research is needed into job search abandonment.

In this paper, I explore the reasons given by long-term unemployed youths in Finland for their decision not to apply for a job or a student place. The analysis is not focused on active labour market policies per se. Rather, I am interested in young people's subjective assessments of their situation and obstacles to job search. The data consist of life course interviews with long-term unemployed youths in Jyväskylä, a city of about 140,000 people in central Finland. The decision to temporarily abandon the search for work or a student place was a recurring theme in the interviews: it was mentioned in 26 of the 28 interviews I collected for my doctoral thesis. Only eight of the excerpts from the data referred to applying for a student place compared with 123 references to searching for work. For simplicity, both are referred to as job search obstacles throughout the remainder of the article.

One of the most crucial decisions shaping the agency of the unemployed individual is whether or not to search for work. The decision hinges on a number of individual characteristics and the individual's life situation, including factors such as work capacity, family and personal finances. Nonetheless, giving up the search for work is not just an individual-level phenomenon. Instead, all job-seeking behaviours are heavily influenced by structural factors, most notably the current labour market situation. This is why the analysis of job search abandonment must incorporate the concepts of both agency and structure. Indeed, agency and structure are the key analytical concepts in this article, in the sense defined by Anthony Giddens in his structuration theory. Giddens's (1979; 1984) idea of strategic conduct is used to identify structural strains that shape and influence the long-term unemployed individual's decision to search for work - or to not to search for work.






\section{Researching temporary job search abandonment}

Giving up the search for work ties in closely with job search intensity. The criteria on which job search intensity is assessed include factors such as the amount of time spent on looking for work and the number of jobs applied for (Kuvaja 2011, p. 18). In Finland, there is a relative scarcity of research into job search intensity among the unemployed (see Virjo \& Aho 2001, p. 55), but internationally, the subject has attracted considerable attention. Another area that has gained much interest is on-the-job search among people who have been laid off or who are changing jobs. The motives and social factors at play in the decision to give up looking for work are somewhat different from those involved in active job search (Vanteenskiste et al. 2004 , p. 347, 360), but job search abandonment is nonetheless rarely examined as a separate research question. Studies on job search intensity and qualitative research into the experiences of the unemployed routinely ignore the reasons for giving up the search for work. Therefore, in order to provide the necessary background for the research question of this article, it is necessary to turn to earlier studies on job search intensity and experiences of unemployment.

Earlier results on the effects of job search intensity on the probability of finding work are mixed: some studies report that high job search intensity increases the prospects of employment (Kanfer et al. 2001, p. 849; Wanberg et al. 1999, p. 904), others indicate that job search intensity has no independent effect on improving employment prospects (Virjo \& Aho 2001, p. 57). It has been shown that individuals who report low levels of job search self-efficacy are less likely to look for work as intensely and are more likely to use ineffective search techniques than individuals with a high level of job search self-efficacy (Wanberg et al. 1999, p. 898-899). In other words, the most active job seekers are the same people who have the best prospects of employment as it is.

Research has found that individuals with a high job search intensity have more mental health issues than those with a lower job search intensity (Bolinder 1999, p. 56; Vuori \& Tervahartiala 1995, p. 47). This finding has been explained by suggesting that active but unsuccessful job search is liable to cause disappointment and frustration and therefore mental ill health (Virjo \& Aho 2001, p. 57). It has been reported that autonomous motivation for refraining from job search is positively related to both general health and life satisfaction (Vanteenskiste et al. 2004, p. 355). Job search intensity is influenced by a variety of situational factors. Illnesses, child care, and family responsibilities, for instance, may contribute to hamper the individual's job search efforts (Vanteenskiste et al. 2004, p. 355; Wanberg et al. 1999, p. 899), whereas financial hardship may be associated with a higher level of job search intensity (Kanfer 2001, p. 844; Wanberg et al. 1999, p. 903).

Psychological studies of job search behaviour draw a close parallel between job search intensity and motivation. According to self-determination theory, motivational intensity is dependent on the extent to which motivation comes from intrinsic as opposed to extrinsic sources (Ryan \& Deci 2004, p. 16). Job search motivation forced upon the individual from the outside is bound to be lower than intrinsic motivation coming from within the individual. Expectation value theory suggests that job search intensity is regulated by expectations of job search success (Feather 1990). The higher people's expectations that they will meet the employer's requirements, the more likely it is they will apply for the vacancy (Savaja 2000, p. 3). 
It seems that low job search intensity is associated with prolonged unemployment (Savaja 2000, p. 58-61; Virjo \& Aho 2001, p. 70), yet it has been reported that the longterm unemployed, on average, have a high work motivation (Aaltio 2014, p. 21). Job search intensity does not decline in the same way across the board: some people who are on union-paid unemployment benefit, for instance, will only begin actively to search for work when they know their benefits will soon be running out (Terävä et al. 2011, p. 57-58). There is also evidence that unemployment benefit sanctions increase the reemployment rate of labour market subsidy and basic unemployment benefit recipients. This, it has been suggested, is explained by the fact that benefit sanctions decrease the reservation wage level and increase the jobseeker's efforts, which positively impacts the likelihood of employment (Busk 2014, p. 65,71). Furthermore, it has been found that job search intensity declines during participation in active labour market schemes (Aho \& Vehviläinen 1997, p. 162; Hämäläinen \& Ollikainen 2004, p. 20; Hämäläinen \& Tuomala 2006, p. 31-32).

Unemployment traps are likewise connected with job search intensity. If income from benefits is close to the level of income from work, then labour supply theory gives cause to assume that unemployment becomes an attractive alternative to gainful employment: it is thought that people will prefer to stay at home on public sector subsidies instead of going out to work (Parpo 2007, p. 18). However, these unemployment trap assumptions are challenged by results from several studies. It seems that people are in fact prepared to accept job offers even if they could earn the same or more from benefits (Forssén \& Hakovirta 1998, p. 26; Hiilamo 2003; Holm \& Kyyrä 1997, p. 39-41; Parpo 2007, p. 46, 72; Pedersen \& Smith 2001, p. 286). One possible explanation is that in the long run, a job that offers no financial incentive may provide a stepping stone to a better paid job in the future.

Overall, there is marked interindividual variation in job search intensity (Savaja 2000, p. 60). However, individual factors impeding employment may have only minor significance and have a limited effect in the labour market. For this reason, an examination of obstacles to employment that is focused on one single factor may leave us with an incomplete picture of the situation of the unemployed (Parpo 2007, p. 57). Job search intensity is often influenced by multiple factors at the same time. Accordingly, the decision to give up the search for work is usually the net effect of several individual and societal factors.

\section{Job search and strategic conduct}

The decision to search or not to search for work is not just individual in nature, because job search can be complicated by a host of structural and labour market factors. Young people are in a weaker labour market position than many other groups. They are often employed in temporary jobs, and they lack the experience that is crucial in the competition for jobs (Nyyssölä 2002, p. 130-131). Tough competition makes the challenge of job seeking even harder. In major Finnish cities where most young jobseekers live, there are usually dozens if not hundreds of job applicants for every job vacancy. This brings us to one of the most fundamental and traditional questions of social research: the question of how the relationship between structures and individual agency is determined in each particular situation. For this reason, the analysis here needs to employ not only the concept of agency but also the concept of structure.

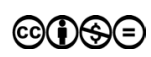


I use the concepts of agency and structure in the sense of Giddens's structuration theory. Giddens says that action refers to intervention in events in the world in order to produce definite outcomes. Agency involves power in the sense of transformative capacity, which can be taken to refer to agents' capabilities to reach wanted outcomes. However, agency has many limitations (Giddens 1979, p. 88; Giddens 1984, p. 15). For example, structures are relatively constant features of society, and individuals cannot just wish them away (Heiskala 2000, p. 187). Nevertheless, structure is not to be equated with constraint, but it is always both constraining and enabling. Structures, as recursively organized sets of rules and as resources, are medium and outcome of the practices they organize (Giddens 1979, p. 70; Giddens 1984, p. 25). The main structures relevant to job search are those related to the labour market and the social security system. These structures provide citizens with access to financial resources on condition that they adhere to a number of informal as well as formal rules. Active labour market policies have also increased demands for active job search and for acceptance of job offers.

Job search abandonment can be seen as a strategic solution for the long-term unemployed in various life situations. In Giddens's terms, the analysis of strategic conduct means giving primacy to strategies of control within defined contextual boundaries. It concentrates on the contextually situated activities of definite groups of actors, drawing attention to 1) agents' knowledgeability, 2) their motivation and 3) dialectic of control (Giddens 1984, p. 288-293). Knowledgeability means that every social actor knows a great deal about the conditions of reproduction in the society of which they are members (Giddens 1979, p. 5). It is important to understand how long-term unemployed youths figure out their labour market position and prospects and how this knowledge affects their job search decisions. Motivational components of action refers to the organization of an actor's wants, straddling conscious and unconscious aspects of cognition and emotion (Giddens 1979, p. 58). By dialectic of control, Giddens means that the less powerful can exert some control over the more powerful (Giddens 1984, p. 374). In our context, this means that unemployed individuals do not blindly follow official rules, but may also act otherwise by circumventing or breaking rules and expectations.

\section{Material and methods}

The data analysed for this research consist of 28 life course interviews running to a total length of 57 hours. $^{2}$ I chose to collect my data in this way because the method agrees well with the notion of strategic conduct that emphasizes individual activity. Seen from the life course standpoint, individuals appear as active agents who have the capacity to shape and direct their life events (Giele \& Elder 1998). Changing lives are in constant interplay with the changes happening in society and its structures. Neither can be understood conceptually without the other (Riley 1998, p. 46). For this reason, it is impossible to consider the meaning of work to young individuals in isolation from their current life situation, the many possible motives they have for working or from the concrete jobs available at each moment in time (Tuohinen 1996, p. 84).

I recruited the interviewees via organizations providing rehabilitation and training services for the unemployed and via the social networks of unemployed youths. All interviewees lived in and around Jyväskylä in central Finland and had been unemployed for at least 12 consecutive months before age 30. Cumulative unemployment duration was 
calculated based on the extended definition of unemployment, which means that participation in active labour market schemes does not interrupt unemployment (Montén \& Tuomala 2003, p. 20).

The life course interviews started from childhood events and proceeded via school years to experiences of work and unemployment, current situation and future plans. The interviews were open-ended and frequently used follow-up questions to gain deeper insight into the youths' experiences. The interviews were analysed using the methods of qualitative content analysis (Cavanagh 1997; Elo \& Kyngäs 2008; Miles \& Huberman 1994, p. 183). Specifically, I used inductive content analysis, which includes open coding, categorization and abstraction (Elo \& Kyngäs 2007, p. 109). I extracted from the material 131 original expressions in which the interviewees discussed their reasons for not having applied for jobs or student places. At the coding stage, I condensed the original expressions (Miles \& Huberman 1994, p. 10-11) into a couple of words that captured the essence of those expressions. For example, the original interview excerpt 'I don't really have the self-esteem to apply for jobs or student places' was condensed into the category 'poor self-esteem'.

Following data condensation, I grouped the data into categories with similar meanings. Each category was named using content-characteristic words (Elo \& Kyngäs 2008, p. 111). At the same time, I abstracted the data in order to proceed from the interviewees' original expressions to theoretical concepts. I continued with this abstraction by combining classifications as far as this was possible from the standpoint of the data. This yielded 25 categories describing reasons for giving up the search for work, which were then combined into six clusters. These clusters were named as disappointments, difficult life situations, lack of knowledge, practical problems, alternative orientation and job contents. Finally, these six clusters were reduced to three theoretical classes: rational, emotional and life value obstacles to job search.

Job search obstacles describe the youths' perspective on the difficulties they had experienced in searching for work. People can react to similar life events in very different ways. Some describe their difficulties in searching for work in very rational terms, the accounts of others revolve around negative emotions and others still say they have lost all interest in work. For this reason, the categories formed in content analysis are not intended as mutually exclusive, but involve some inevitable overlap. The key decisive factor with respect to the classification is the interviewees' articulation: do they describe their job search rationally, in emotional terms or from the standpoint of their life values. Quite often the interviewees' narratives combined different types of explanations. The interviewees' names have been changed and all other identifying data removed for reasons of anonymity. Filler words have been edited out for readability.

\section{Rational job search obstacles ${ }^{3}$}

Rational narratives of job search obstacles provided sound and well-justified reasons for why the interviewees had given up searching for work. Rational accounts of life situations may otherwise be very similar to emotional narratives of job search obstacles, but they do not mention the negative emotions attached to searching for work. The two major rational job search obstacles mentioned in the interview narratives were practical problems and lack of knowledge.

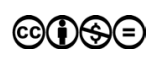




\section{Practical problems}

Practical problems refer to the rational reasons why, from the unemployed youth's standpoint, it does not make sufficient sense to apply for a job offered, or indeed why accepting a job is impossible. Practical problems are concrete barriers to job search. When speaking about these problems, young people are also able to rationalize the strategic decisions they have made. In Giddens's (1984, p. 5) terms, the rationalization of action means that agents can maintain a continuing theoretical understanding of the grounds of their activity. Youths are very knowledgeable of their situation and give well reasoned arguments as to why they have decided not to search for work. In their interviews, the youths mention virtually all the known reasons for structural unemployment, that is qualifications, vocational skills and training, the applicant's geographical residence and work experience, which differ from the job vacancies available (see Pehkonen 1998, p. 319). The locking-in effect associated with active labour market measures, that is the reduced intensity of job search during these measures (Hämäläinen 2013, p. 179), is also seen in the interviews.

Another practical problem raised in the interviews is poor health. A poor state of health is usually connected with difficult life situations, but even health can be approached in purely rational terms. Seen from this standpoint, health is reduced to an issue of disability and does not necessarily involve any emotional burden. Other factors impacting young people's job search include unemployment (Parpo 2007) and bureaucracy traps (Hiilamo 2010, p. 277) as well as poor prospects for employment. Resulting from structural incongruities between the social security system and the labour market, unemployment and bureaucracy traps effectively undermine the willingness of young people to apply for short-term jobs. Vocational school graduate Jaana (29) said this in her interview:

\footnotetext{
SY: So have these jobs affected your benefits?

J: Well it's really hard to go because you're listed as unemployed again and all your benefits are completely screwed up.

SY: Can you elaborate on that?

J: Well there's a long period when you don't get any money at all and you have all these waiting periods and stuff, and then sometimes they've like offered me temporary jobs, I mean real short ones, they're absolutely not worth it. They just mean you'll be left with less income than before.

SY: So you're left with less money in pocket?

J: Yeah I'd almost say that's the case. At least you won't be getting more. I mean like a two-week job, you won't - all the paperwork that's involved, you just can't be bothered.
}

Jaana gives a rational description of the unemployment and bureaucracy traps related to short-term temporary jobs. She says the financial benefits from accepting such a job are minimal or even negative. This meets the criterion of an unemployment trap, as the individual's net income would not increase from the amount they receive in benefits. Jaana also describes the huge amount of paperwork involved. Even after a brief spell at work, the unemployed have to reapply for benefits, which is a long drawn out process causing delays in payments and financial uncertainty. Short-term temporary jobs also complicate everyday life and planning ahead, as the rules involved are often strictly binding 
upon employees. Anyone interested in working for the same company in the future must be prepared to accept even the shortest jobs at very short notice. These factors figure prominently in the long-term unemployed youths' narratives as to why they are reluctant to apply for temporary jobs shorter than two weeks. As far as they are concerned, short temporary jobs are a burden for the unemployed youths, because the short notice complicates everyday life and the benefit system plays havoc with daily finances. It is a reasonable strategic decision to decline these kinds of job offers.

Many of the youths interviewed have poor prospects of employment, which they often recognize themselves. Some are able to take a rational view of their situation. One of the reasons why they think their chances of getting work are minimal is that there simply are not enough vacancies in their sector. Some interviewees say it is impossible for them to compete with the countless other applicants. They also recognize that they have gaps in their qualifications, which will hurt their chances of getting a job. If they think their prospects of finding work are poor, making an effort and pushing hard to land a job will not necessarily seem a very rational thing to do.

\section{Lack of knowledge}

The youths often say in their interviews that they do not have the necessary knowledge to search for work. It is hard for them to apply for jobs because they are not sure in which sector they would want to work, because they have no clear plans for employment, or because they lack knowledge about work and careers in general. Giddens points out that agents' knowledgeability is always limited in respect of boundaries of action (Giddens 1979 , p. 144), but in this case, the information needed for strategic decision-making in respect of job search is almost totally absent. Intentional action always requires that agents utilize their knowledge to achieve particular outcomes (Giddens 1984, p. 10). This is why intentional action is almost impossible without a clear notion of the ultimate aim of that activity or the means with which it can be achieved. For this reason, lack of knowledge is a problem first and foremost of rational decision-making, and it hampers intentional, goal-oriented activity in the labour market. Urho (30) is an example of a person who for these reasons has had great difficulty orienting to the labour market.

U: Well at the point when you knew what you were going to apply for, it wasn't at that stage really difficult at all. Which it was when you still didn't know what sector you'd like to get into. I mean it was impossible to get started in that situation. But now that you had work experience, a degree and when you knew what you wanted, at that stage it was real easy.

SY: Okay.

U: You knew what you're doing.

SY: Was there earlier some sort of mental barrier to searching for work?

$U:$ Yeah I'm sure there was. And there was the uncertainty that you didn't know what you wanted. Perhaps that was the main thing. The main problem. You needed really to find that one thing before you could seriously turn your attention to the labour market.

Urho is a typical example of a person whose youth has been characterized by aimlessness. This is a result of not knowing what one wants from life. Urho dropped out of his 
first degree programme because he lacked interest and motivation, but he later completed another vocational degree. In his own words, he 'did nothing' with this degree. Later on, he 'couldn't even be bothered to look for any work', and he was unemployed for some four years. Because of their lack of knowledge, the interviewees have had difficulty identifying and understanding the structures of society in which they are expected to lead their lives. They said they often were not even interested to find out, hinting at difficulties with strategic decision-making and future planning that in the absence of outside help may persist for years. Indeed, an intervention by some outside party often appears in the youths' narratives as a turning point in their lives.

In Urho's case, this turning point came in the form of a job offer from the employment office. This eventually brought him a trainee position with another employer, which proved to be a good experience. Finding a meaningful job and the experiences of success provided a clear direction for Urho's future planning. He later applied for other trainee positions in the same sector and completed a degree. The key factor that helped Urho turn the corner and encouraged him to start looking for work was the discovery of his 'own thing', which he felt he was good at and which he 'liked doing'. As a result, this passive unemployed youth transformed into an active and keen job applicant who soon found a job after graduating. He has now been working for several years and his future work prospects are good.

Urho is no exception. In fact, there were quite a few youths who contemplated out loud about 'what would be an interesting sector' or who said they 'hadn't found a suitable job' or that they 'haven't got a clue what to apply for'. It seems that young people lack the experience that would help them decide which sector and field would suit them best. In the absence of this experiential knowledge, their career plans remain vague and abstract. This lack of clarity translates into hard-to-achieve goals and objectives, which in turn are associated with more psychological distress (Emmons 1992). It is also clear from the interviews that the youths have many gaps in their knowledge about work and careers in general, as they consider which sectors and fields offer the best prospects of finding work, as they have no idea of the qualifications required in different jobs and occupations, and as they may also be unclear about application procedures to different schools and institutions. Their lack of knowledge is often reflected in a rather fatalistic discourse in which the narrator's own role is pushed to the margin. In this connection, the youths use such expressions as 'we'll just have to see what turns up' and 'they know what they're doing at the employment office', in which the narrator has no active role in the unfolding of events. This kind of narrative suggests a reduced ability to plan ahead for the future and make strategic decisions.

\section{Emotional job search obstacles ${ }^{4}$}

Emotional obstacles to job search are characterized by an emotionally laden narrative. The youths refer to the negative emotions elicited by looking for work, which often have to do with the stress involved. Stress tends to surface in situations that people think may threaten their well-being and exceed or tax their existing resources (Folkman et al. 1986, p. 992-993). It is clear from their narratives that these youths are keenly aware of the environment's pressures and expectations with regard to their looking for work, but they feel there is very little they can do to influence the situation. In an objective 
assessment, they might have had some options, but the applicants have either not been aware of them or concluded that it would be too hard to achieve them. Consequently, the youth start to avoid searching for work because they do not want to face the associated negative emotions. Emotional job search obstacles are caused by disappointments and difficult life situations.

\section{Disappointments}

Disappointments highlight the emotional reactions associated with job search failure, being rejected and giving up. In their narratives of disappointment in connection with job search, the youths usually describe their unemployment as a forced situation. They had tried to find work, but failed time and again. Seen from their own standpoint, the interviewed youths had hardly any realistic means of influencing their prospects of finding work, but they just had to resign to the situation. Individuals have virtually no input into such external factors as employers' hiring criteria, including years of experience and job specific skills (Fugate et al. 2004, p. 16). The story of Lauri (31) is one example of trying but failing. He has two vocational degrees and has been out of work for a total of almost eight years, during which time he has taken part in countless active labour market measures. Even so during his lifetime, he has been in paid employment for just one single month. He describes his job search as follows:

\footnotetext{
SY: Have your experiences of unemployment changed over time?

L: Sure yes, or how should I put it. Or you just can't be bothered any more to really try. Early on I'd use to send in no end of applications and apply everywhere, even if I really wasn't even qualified.

SY: So you'd be actively searching for work?

L: Yeah, but I mean you get fed up. It becomes a shitty job in itself, looking for work and running around all these places and failing all the time. It's a real drain. You know, why go to the trouble to apply cos it's always the same, yeab yeab you were the best applicant in the world but unfortunately we're not hiring you but we chose this other poor sod.
}

Lauri's story is a typical example of the disappointments associated with job search failure. These young people who have been disappointed in their efforts to find work insist they have tried really hard, but repeatedly failed. These failures can also be addressed in a purely rational manner, but they transform into disappointments when they have a negative emotional charge. In Lauri's case, his job search disappointments changed an initially active and eager applicant into a pessimistic and passive unemployed youth. In his own words, the constant failure of his efforts made the search for work a 'shitty' business and he became 'fed up'. My interpretation is that Lauri's frustrated outbursts and anger stem from his sense of disappointment (see Lähteenmaa 2010, p. 59). Likewise, the comment that the efforts invested in job search are a 'real drain' is clearly linked with the mental stress caused by job search. Disappointments make searching for work a mentally strenuous exercise and therefore the decision to give it up makes perfect sense to young people as a strategic choice. This brings youths face to face with society's high expectations regarding active employment and often spurs them to resume their efforts later on. The life course of the youths interviewed is typically a succession 
of active job search periods lasting from a couple of days to up to months, which are interspersed with sometimes much longer periods of suspended job search.

\section{Difficult life situations}

Difficult life situations refer to emotionally exhausting stages in young people's life courses. Examples of such situations include mental health problems, burnout, substance abuse, broken relationships and the death of a close person. These same issues can also be addressed in entirely rational terms, but only those expressions are classified in this category that specifically mention the negative emotions aroused by the situation. Difficult life situations also differ from disappointments in the sense that in most cases, youths have not even managed to start looking for work. Difficult life situations are life events that Giddens (1984, p. 61; 1979, p. 123-128) calls 'critical situations' and in his later production 'fateful moments'. These are life situations in which daily routines become radically disrupted (Giddens 1991, p. 167). Routines are central to the individual's sense of ontological security, and therefore, any disruption to those routines gives rise to anxiety, pain and fear (Giddens 1979, p. 123-128; 1991, p. 167). For this reason, difficult life situations bring negative emotions to the surface. Jaana (29) discusses the effects of mental health problems on her job search:
$J:$ And it was perhaps also a bit that I wanted to take distance from society and the require- ment that you have to work.
SY: How long did this desire to take distance last?
J: I felt that in summer 2006 I came to a turning point that I wanted to change my life.
SY: So that was some six years ago?
J: Right and that was when I began actively to search for work.
SY: Did something special happen at that point?
J: I got medication for depression and the doctor said I needed to have thyroid tests and then they discovered that I had hypothyroidism and I got medication for that and that changed my mood.
SY: And as a result apparently your attitude to work changed as well?
J: So there was this depression and that was a big reason why I didn't want to work.

This account is a typical example of the difficult life situations experienced by the youths interviewed in that it was only after Jaana had resolved her problems that it became possible for her to become oriented to the labour market. Jaana struggled for years with severe depression, which was a major reason for her tendency to withdraw and her reluctance to search for work. Jaana herself attributed her depression to traumatic childhood events, including her mother's early death and a troubled relationship with her stepmother. These issues remained suppressed for years, and Jaana believes this was what triggered her depression, which was further exacerbated by hypothyroidism.

After she graduated from vocational school, Jaana was unemployed for around six years. Typically, youths in difficult life situations have most of their resources tied up in coping with the everyday grind. They will have very little left in the tank to search for work, which may seem like a challenge too far and therefore a source of negative 
emotions. Jaana says that 'I haven't been active [searching for work] because it all feels so difficult. Sometimes if I really put my head down I might have one day when I phone around', but that 'requires a huge effort and you can't do that every day'. This is indicative of a mental barrier to searching for work that has to be overcome in order be able to apply for jobs.

According to Giddens (1991, p. 167), individuals facing fateful moments may feel particularly bereft and suffer from a lack of psychic and social resources to cope with a difficult situation. They might be unable to solve their problems by themselves. Indeed, many of the interviewed youths who received no outside help continued to struggle with difficult life situations for prolonged periods. For Jaana, too, admission to care marked a clear turning point because when her depression began to lift, her interest in work was soon revived. Her unemployment ended as she began to study, and as soon as she graduated, she found a job in her own sector. Her future employment prospects are solid.

\section{Job search obstacles related to life values ${ }^{5}$}

Job search obstacles related to life values arise from what young people consider important or valuable in their life. They are based on young people's value choices and may therefore seem illogical or hard to understand to an outsider. Even so, the reluctance of the unemployed to participate in the social fabric of society can be understood in terms of strategic conduct. Wage employment is not necessarily an important value for young people; other aspects of life may well take precedence. People who attach little value to work will not have a very high level of job search intensity (Savaja 2000, p. 67). The explanations offered by the youth for their reluctance to search for work appear in the form of an alternative orientation or questions concerning the contents of work.

\section{Alternative orientation}

Job search problems associated with an alternative orientation call into question the meaning of work in the young individual's life as a whole. Youths with an alternative orientation harbour deep-seated resentment against the values of modern society, particularly wage employment, technology and materialism (Wrede-Jäntti 2003, p. 106-109; Wrede-Jäntti 2010, p. 109-110). In the life course of the young people interviewed for this research, periods of alternative orientation varied in length from a few weeks to more than a year. The most distinctive feature of this orientation is that the young individual places greater value on leisure or some other activity than on wage employment. Typically, these individuals will talk about taking a break, their own activities and the unimportance of work. Taking a break refers to periods of life when youths are officially unemployed but concentrate on spending free time or just chilling out. It often serves as a buffer between different life situations. Not all young people are actively searching for work, but they may be waiting for the start of a training course (Malmberg-Heimonen 2003 , p. 44), a job or military service, or because they are expecting a baby. Short-term breaks are also taken in the early stages of unemployment. Sirpa (29) has just graduated from a nursing programme:

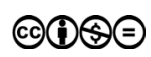


This two-year programme period was in fact quite intense and there were lots of job training placements and there were no holidays at all so I was bit like, now that I'm unemployed from Christmas I'll certainly register as an unemployed job seeker at the employment office and look around a bit, but I won't apply for anything. Just so that I could take a short break. And then when I felt I'd had my Christmas holidays I started to look for work again.

Sirpa is a typical example of a young person who takes a short break after graduating (see also Sundvall 2013, p. 63). She temporarily values her own leisure as more important than searching for work. Even so it is fair to say that Sirpa is motivated to search for work, and there is no reason to believe she will have any long-term difficulty finding employment. Some, however, remain in this break mode for much longer. Among the interviewees, there were two young people who said they had been on a gap year after upper secondary school and before beginning their studies. I also interviewed one housewife who had spent about one year of her unemployment looking after her small child at home. As a rule, the youths interviewed describe their breaks as a passing stage of life. Yet, in a couple of cases, the youths' reluctance to search for work has been due their aversion to work in general. This is reflected in expressions of the perceived unimportance of work: 'wanted to be unemployed', 'forgot about job search' and 'had no interest'. Later, however, even these youths changed their mind and oriented themselves to the labour market.

The value of wage employment may also be superseded by personal interests and activities. Youths with an alternative orientation are keen to invest in what they think is most interesting in life, what they like and value most of all (Wrede-Jäntti 2003, p. 106). The youths said time and again that they did not want to spend their days doing nothing, and therefore had to invest much time and effort in finding outlets for selfrealization in alternative projects to wage employment. The following excerpt is from an interview with Daniel (23):

I can say for sure that it would be extremely easy just to stay put and to build your life around social welfare and then just mess around with what you want. Whatever you want to do. When they say that I mean it didn't seem at all impossible to live your life outside society. Just take advantage of what you can get out of society. Yeah and I mean it's just about concentrating on your own belly button.

Although he is currently in workplace training, Daniel is leading an active life. He has several leisure interests and he is involved in organizations, voluntary work and organizing events. After upper secondary school, he spent a few years 'messing around' with his own stuff and was not interested in work. He has since changed his mind and is now committed to finding work. Daniel is an exceptional individual in the sense that he refers to social welfare as he explains his previous attitude to searching for work. He mentions the social services centre and the income support he received from the centre, which made possible the lifestyle he had at the time. Only three other interviewees mentioned the impact of the benefits or allowances they received to their job search. By all accounts, it seems that social security lowers the threshold for youths to adopt alternative lifestyles in that it guarantees them a basic income. Yet, a far more important incentive to adopting an alternative orientation is the difficult 
labour market situation that makes it virtually impossible to find work. The logical strategic solution in this situation is to try and find meaningful content in one's life from sources other than wage employment.

\section{Job content}

Job content is another reason why youths may drift into passivity in their search for work. The single most important aspect of work, for the vast majority of young people, is job content, what one actually will be doing on the job (Myllyniemi 2007, p. 39). This is clearly reflected in the interviews collected. A high level of education underscores the meaning of job content (Tuppurainen 2010, p. 18-19), which provides the motivational foundation for the choice of sector of employment in virtually all education and counselling ideologies in Finland (Tuohinen 1996, p. 81). Against this background, it is understandable that job content values are highly prominent in the interviews of long-term unemployed youths. Young people know what kind of work they would want to do and expect their job to provide opportunities for self-realization. They also expect to find a job commensurate with their skills and qualifications. Job content values narrow the range of jobs that young people will apply for. If jobs are not available that match their values, then job content issues may prevent the individual from searching for work at all. Jaakko (30) describes the influence of job content on his search for work:

SY: What about searching for work? How active were you in terms of sending in job applications when vacancies were announced?

J: Well I could have been more active than I was, but the thing was that in many cases you really needed a lot of experience. Especially if you wanted a proper job as a chef, not just any old job, then the minimum requirement was at least two years' professional experience. I personally haven't been too keen on travelling all the way to Lapland or what have you, where it's easier to get a job, where you could have got that experience ... [I've] really put down roots here in Jyväskylä.

Jaakko refers to both rational arguments and job contents to explain his low job search intensity. His rational reasons include the lack of experience and his reluctance to move after work. However, he is also clear that he does not want to do odd jobs, but is keen to find work that matches his qualifications as chef. His reference to 'any old job' implies work that is not respected. Jaakko feels that his job search was hampered because he could not realistically expect to find work in Jyväskylä that was commensurate with his qualifications. The youths interviewed said that they would apply for jobs in other sectors when they were out of work for long periods, but would always do so with caution and consideration. Job content is not just a matter of opinion about what is and what is not meaningful work. It also has to do with how the individual's skills, training, qualifications and other characteristics can be applied to the concrete jobs available. Physical and mental limitations, for instance, may have a major influence on the kind of work that a young person can consider and accept. For instance, vertigo sufferer Risto (25) said he could have had a job removing snow from the top of buildings, and Liisa (20) said 'it would be embarrassing to throw up while you're changing old ladies' nappies'. 
Neither had applied for these jobs that the employment office had offered them because they thought the specific job tasks would have required unreasonable effort.

\section{Conclusion}

The interview data analysed in this research describe how long-term unemployed youths in central Finland view obstacles to job search. There seems to be a broad sense that looking for work is not really worth while: there is no real incentive because there just are not enough jobs to go around. The young people reacted to this in very different ways. Some chose not to search for work at all because of the mental stress involved, or because it arouses intense negative emotions. Emotional barriers come up in connection with disappointments and difficult life situations that must be overcome before it is possible to search for work in the first place. Others take a very rational view on the problems of searching for work: because of their lack of knowledge or because of the practical problems involved, it is sometimes unreasonable or indeed impossible for longterm unemployed youths to try and find work. A third approach that leads young people to abandon their search for work is based on their value choices. These choices have to do with job content and more generally with the meaning of work in the young individual's life. Employers' high demands and qualification requirements (Sundvall 2013, 63) make it virtually impossible for young people to find employment, especially if they have any disabilities. A logical strategic solution in this situation is to search for meaningful content in one's life within some other domain.

Giving up the search for work is a rather complex phenomenon. The youths interviewed here often discussed job search obstacles in various combinations. For the same reason, the decision to temporarily abandon one's job search cannot be seen as a purely individual choice. The young person's life history and environment have a major impact on the decisions they make. As Giddens (1984) shows in his theory, agency and structure are closely interwoven. Likewise, the references in young people's narratives to structural and individual obstacles to job search are closely intertwined. They mention a number of reasons that have to do with their individual life situations, but in many cases, these only become true obstacles to job search when the prevailing labour market situation is also taken into account. From a theoretical standpoint, there have no doubt been many opportunities in the lives of the youths interviewed that they have failed to grasp. In reality, they have faced numerous obstacles in their lives that have prevented them from recognizing or seizing these opportunities.

The results of this research have relevance in all countries where the unemployed are faced with similar requirements in the labour market. In the Nordic countries and most other Western societies, it is a common misunderstanding that unemployment is somehow linked to a lack of work ethics or some other personal shortcomings rather than to structural causes (Hobbins 2016, 43). Reflecting this misperception, labour market policies clearly fail to recognize the impact of labour market structures on the individual's strategic conduct. This failure is then reflected in an overemphasis on individual factors that affect job search behaviour. This simplistic view is almost the exact opposite to the reality faced by long-term unemployed youths. The main reason why they decide to abandon their job search from time to time lies in the strained labour market situation. The reason they soon resume their search, in turn, lies not only in the expectations 
of the society around them but also their willingness to find work. The long-term youth interviewed for this study considered employment a valuable goal. For this reason, weak work ethics cannot explain why the long-term unemployed youths decide to give up their job search. Instead, we need to turn our focus to the life situation of the youth and understand the structural labour market factors.

\section{References}

Aaltio, E. (2014). Työllisyyspalvelujen toimintakykymittarin pilotointi. Työllisyyspalveluiden vaikuttavuus -projektin väliraportti. [Piloting a functional capacity scale for employment services. Interim project report.], Helsinki: Kuntaliitto.

Aho, S. \& Vehviläinen, J. (1997). Keppi ja porkkana. Tutkimus alle 20-vuotiaita aktivoivan työvoimapoliittisen uudistuksen vaikutuksista ja koulutuksen ulkopuolelle jäävistä nuorista. [Stick and carrot. Study on the impacts of a labour policy reform designed to activate young people aged under 20 and on young people excluded from education.], Helsinki: ESR-julkaisut 3/97.

Bolinder, M. (1999). Söksbeteendets betydelse för chansen att hitta ett job. [Significance of job search behaviour for chances of finding a job.], Arbetsmarknad \& Arbetsliv 5 (1): 45-62.

Breen, R. (2005). Explaining cross-national variation in youth unemployment. Market and institutional factors, European Sociological Review 21(2): 125-134. doi: https://doi. org/10.1093/esr/jci008.

Busk, H. (2014). Search in the Labour Markets. Empirical Evidence of the Role of Technology and Sanctions. Väitöskirja, Jyväskylä: Jyväskylä University School of Business and Economics (151).

Cavanagh, S. (1997). Content analysis: concepts, methods and applications, Nurse Researcher 4 (3): 5-16. doi: https://doi.org/10.7748/nr1997.04.4.3.5.c5869.

Dietrich, H. (2012). Youth Unemployment in Europe. Theoretical Considerations and Empirical Findings, Bonn: Friedrich Ebert Stiftung.

Elo, S. \& Kyngäs, H. (2008). The qualitative content analysis process, Journal of Advanced Nursing 62(1): 107-115. doi: https://doi.org/10.1111/j.1365-2648.2007.04569.x .

Emmons, R. (1992). Abstract versus concrete goals. Personal strivings level, physical illness and psychological well-being, Journal of Personality and Social Psychology 62(2): 292-300. doi: https://doi.org/10.1037//0022-3514.62.2.292.

Eurostat (2017). Newsrelease euroindicator 166/2017. October 2017.

Feather, N. (1990). The Psychological Impact of Employment, New York: Springer-Verlag. doi: https://doi.org/10.1007/978-1-4612-3250-6.

Folkman, S., Lazarus, R. \& Dunkel-Schetter, C. \& DeLongis, A. \& Gruen, R. (1986). Dynamics of a stressful encounter: cognitive appraisal, coping and encounter outcomes, Journal of Personality and Social Psychology 50(5): 992-1003. doi: https://doi.org/10.1037//00223514.50.5.992.

Forssén, K. \& Hakovirta, M. (1998). Work Incentives in Single Parent Families, Turku: Turun yliopisto, Sosiaalipolitiikan laitos. Series B/15.

Fugate, M., Kinicki, A. \& Ashford B. (2004). Employability: a psycho-social construct, its dimensions and applications, Journal of Vocational Behavior 65(1): 14-38. doi: https:// doi.org/10.1016/j.jvb.2003.10.005.

Giddens, A. (1991). Modernity and Self-Identity. Self and Society in the Late Modern Age, Stanford: Stanford University Press.

Giddens, A. (1984). The Constitution of Society, Cambridge: Polity Press.

Giddens, A. (1979). Central Problems in Social Theory: Action, Structure, and Contradiction in Social Analysis, Berkeley and Los Angeles: University of California Press. 
Giele, J. \& Elder, G. (1998). Life course research: development of a field. In: J. Giele \& G. Elder (eds.) Methods of Life Course Research: Qualitative and Quantitative Approaches, London: Thousand Oaks: 5-27. doi: https://doi.org/10.4135/9781483348919.n1.

Heiskala, R. (2000). Toiminta, tapa ja rakenne. Kohti konstruktionistista synteesiä yhteiskuntateoriassa. [Action, habit and structure. Towards a constructionist synthesis in social theory.], Helsinki: Gaudeamus.

Hiilamo, H. (2003). Työ kannustaa enemmän kuin laskelmat osoittavat. [Work has stronger incentive effect than calculations indicate.], Yhteiskuntapolitiikka 68(1): 83-89.

Hiilamo, H. (2010). Pitkäaikaistyöttömän sosiaaliset mahdollisuudet. [The social opportunities for the long-term unemployed.] In: H. Hiilamo \& J. Saari (toim.) Hyvinvoinnin uusi politiikka - johdatus sosiaalisiin mahdollisuuksiin. [New welfare policy - an introduction to social opportunities.], Helsinki: Diakonia-ammattikorkeakoulu: 265-286.

Hobbins, J. (2016). Young long-term unemployed and individualization of responsibility, Nordic Journal of Working Life Studies 6(2): 43-59. doi: https://doi.org/10.19154/njwls. v6i2.4965.

Holm, P. \& Kyyrä, T. (1997). Tulojen vaikutus työmarkkinasiirtymiin. [Effect of incomes on labour market transitions.] VATT-tutkimuksia 40, Helsinki: VATT.

Hämäläinen, K. \& Ollikainen, V. (2004). Different Effects of Active Labour Market Programmes in the Early Stages of Young People's Unemployment. VATT-tutkimuksia 115, Helsinki: VATT.

Hämäläinen, K. \& Tuomala, J. (2006). Työvoimapoliittisten toimenpiteiden vaikutusten arviointi. [Evaluating the effects of labour policy measures.] Työpoliittinen tutkimus no: 315, Helsinki: Työministeriö.

Hämäläinen, K. (2013). Aktivointipolitiikan talouspoliittiset tavoitteet, tulokset ja merkitys yhteiskunnassa. [Economic policy aims, outcomes and significance of activation policy in society.] In: V. Karjalainen \& E. Keskitalo (toim.) Kaikki työuralle! Työttömien aktiivipolitiikkaa Suomessa. [Activating the unemployed in Finland.], Helsinki: THL: 173-189.

Johansson, H. \& Hviden, B. (2007). Re-activating the Nordic welfare states: do we find a distinct universalistic model? International Journal of Sociology and Social Policy 27(7): 334-346.

Kanfer, R., Connie, W. \& Kantrowitz, T. (2001). Job search and employment: a personalitymotivational analysis and meta-analytic review, Journal of Applies Psychology 86(5): 837-855. doi: https://doi.org/10.1037//0021-9010.86.5.837.

Karjalainen, V. (2013). Aktivointipolitiikan ajankohtaisuus. [Activation policy now.] In: E. Keskitalo \& V. Karjalainen (toim.) Kaikki työuralle! Työttömien aktivointipolitiikkaa Suomessa. [Activating the unemployed in Finland.], Helsinki: THL: 207-224.

Keskitalo, E. (2008). Balancing Social Citizenship and New Paternalism. Finnish Activation Policy and Street-level Practice in a Comparative Perspective. Research report 177, Helsinki: Stakes.

Keskitalo, E. \& Karjalainen, V. (2013). Mitä on aktivointi ja aktivointipolitiikka? [What is activation and activation policy?] In: Elsa Keskitalo \& Vappu Karjalainen (toim.) Kaikki työuralle! Työttömien aktivointipolitiikkaa Suomessa. [Activation policy for the unemployment in Finland.], Helsinki: THL: 7-18.

Kuvaja, A. (2011). Työttömien työnhakumotivaatio ja motivointi: Sosiaalitoimen työvalmentajien näkökulmia. [Motivating the unemployed to search for work: perspectives of social services' job coaches.], Helsingin yliopisto: Sosiaalityön erikoistumiskoulutuksen lisensiaatintutkimus.

Lähteenmaa, J. (2010). Nuoret työttömät ja taistelu toimijuudesta. [The young unemployed and the battle for agency.] Työpoliittinen aikakauskirja 4/2010, Helsinki: Työministeriö: 51-63.

Malmberg-Heimonen, I. (2003). Urbaanin nuoren työttömyys. [Unemployment of the urban youth.] In: I. Malmberg-Heimonen, L. Siurala \& M. Wrede-Jäntti (toim.) Tulkintoja 
nuorisotyöttömyydestä. [Interpretations of youth unemployment.], Helsinki: Kaupungin tietokeskus: $25-84$.

Miles, M. \& Huberman, M. (1994). Qualitative Data Analysis. An Expanded Sourcebook, Thousand Oaks: Sage.

Montén, S. \& Tuomala, J. (2003). Alueellinen työttömyys ja pitkäaikaistyöttömyys 1990luvulla. [Regional unemployment and long-term unemployment in the 1990s.], Helsinki: Valtion taloudellinen tutkimuskeskus.

Myllyniemi, S. (2007). Perusarvot puntarissa. Nuorisobarometri 2007. [A survey of basic values among youths in 2007.] Nuorisotutkimusverkosto/Nuorisotutkimusseura, julkaisuja 79, Helsinki: Opetusministeriö.

Myrskylä, P. (2010). Taantuma ja työttömyys. [Recession and unemployment.] Työ ja elinkeinoministeriön julkaisuja. Työ ja yrittäjyys 57/2010, Helsinki: Työ- ja elinkeinoministeriö.

Nyyssölä, K. (2002). Valmennusta ja varastointia. Nuorten työllisyys ja työvoimapolitiikka 1960-luvulta 2000-luvulle. [Coaching and stockpiling. Youth employment and labour policy from the 1960s to the 2000s.] In: H. Silvennoinen (toim.) Nuorisopolitiikka Suomessa. 1960-luvulta 2000-luvulle. [Youth policy in Finland. From the 1960s to the 2000s.], Helsinki: Nuorisoasiain neuvottelukunta: 120-136.

Parpo, A. (2007). Työllistymisen esteet. [Obstacles to employment.] Stakes Raportteja 11/2007, Helsinki: Stakes.

Pedersen, P. \& Smith N. (2001). Unemployment traps: do financial disincentives matter? European Sociological Review 18(3): 271-288.

Pehkonen, J. (1998). Työmarkkinoiden kohtaanto ja alueelliset työttömyyserot. [Labour market mismatch and regional differences in unemployment.] In: M. Pohjola. (toim.) Suomalainen työttömyys. [Finnish unemployment.], Helsinki: Taloustieto: 317-336.

Riley, M. (1998). A life course approach: autobiografical notes. In: J. Giele \& G. Elder (eds.) Methods of Life Course Research: Qualitative and Quantitative Approaches, London: Thousand Oaks: 28-51.doi: https://doi.org/10.4135/9781483348919.n2.

Ryan, R. \& Deci, E. (2004). An overview of self-determination theory. An organismic dialectical perspective. In: E., Deci \& R., Richard (eds.) Handbook of Self-Determination theory, Rochester: University of Rochester Press: 3-33.

Savaja, E. (2000). Työttömien ja työvoimapoliittisissa toimenpiteissä olevien työnhakukäyttäytyminen. [Job search behaviour of the unemployed and participants in active labour policy measures.], Helsinki: Taloustieto.

Sundvall, S. (2013). Nuorten työnhakuun liittyviä kokemuksia Uudeltamaalta. [Young people's experiences of job search in Uusimaa.] Työpoliittinen aikakauskirja 4/2014, Helsinki: Työ- ja elinkeinoministeriö: 60-64.

Terävä, E., Virtanen, P., Uusikylä, P. \& Köppä, L. (2011). Vaikeasti työllistyvien tilannetta ja palveluita selvittävä tutkimus. [Study on the situation and services available for the hard-toemploy.] Työ- ja elinkeinoministeriön julkaisuja. Työ ja yrittäjyys. 23/2011, Helsinki: Edita.

Thompson, Spencer (2013). States of Uncertainty. Youth Unemployment in Europe, London: Institute for Public Policy Research.

Tuohinen, T. (1996). Isät, pojat ja pärjäämisen henki. [Fathers, sons and the spirit of managing.] In: T. Hoikkala (toim.) Miehenkuvia. Välähdyksiä nuorista miehistä Suomessa. [Images of young men in Finland.], Helsinki: Gaudeamus: 66-101.

Tuppurainen, S. (2010). Nuorten asenteita työtä, työn sisältöä ja koulutusta kohtaan. [Young people's attitudes to work, job content and training.] Työpoliittinen aikakauskirja 4/2010, Helsinki: Työministeriö: 14-22.

Vanteenskiste, M., Lens, W., De Witte, S., De Witte, H. \& Deci, E. (2004). The 'why' and 'why not' of job search behavior. Their relation to searching, unemployment experience and well-being, European Journal of Social Psychology 34(3): 345-363. 
Virjo, I. \& Aho, S. (2001). Työnhakuaktiivisuuteen vaikuttavat tekijät. [Factors impacting job search intensity.] Työpoliittinen aikakauskirja 3/2001, Helsinki: Työministeriö: 55-76.

Vuori, J. \& Tervahartiala, T. (1995). Työttömien työnhakuaktiivisuus ja koettu terveys. [Job search intensity and perceived health among the unemployed.], Helsinki: Työministeriö.

Wanberg, C., Kanfer, R. \& Rotundo, M. (1999). Unemployed individuals: motive, job-search compentencies and job-search constraints as predictors of job seeking and re-employment, Journal of Applied Psychology 84 (6): 897-910. doi: https://doi.org/10.1037/00219010.84.6.897.

Wrede-Jäntti, M. (2003). Työ, rahat tai henki! - nuorten helsinkiläisten työttömien toimintastrategioita. [Coping strategies of young unemployed people in Helsinki.] In: I. Malmberg-Heimonen, L. Siurala \& M. Wrede-Jäntti (toim.) Tulkintoja nuorisotyöttömyydestä. [Interpretations of youth unemployment.], Helsinki: Kaupungin tietokeskus: 25-84.

Wrede-Jäntti, M. (2010). Pengarna eller livet? En kvalitativ och longitudinell studie om långtidsarbetslösa unga i ett aktörsperspektiv. [A qualitative and longitudinal study of longterm unemployed youth from an actor perspective.], Helsinki: Institutet för hälsa och välfärd.

\section{NOTES}

1 In October 2017, the Finnish seasonally adjusted youth unemployment rate was $20.4 \%$, compared with $16 \%$ in the EU28 and $18.6 \%$ in the euro area. (Eurostat 2017)

2 The data were collected in collaboration with the research project 'Job-seeking Groups and the Restructuring of Opportunities in Finland since the 1990s', which was financed by the Academy of Finland. The interviews were carried out by Sami Ylistö, Päivi Kivelä and Professor Martti Siisiäinen between May 2012 and February 2013.

3 Rational obstacles were the most common reason mentioned for giving up the search for work $(\mathrm{n}=24)$.

4 Emotional obstacles were the second most common reason mentioned for giving up the search for work $(n=23)$.

5 Job search obstacles related to life values were by far the least common reason mentioned for giving up the search for work $(\mathrm{n}=12)$. 